\title{
ガスアトマイズ法における噴流エネルギーと粉砕仕事の関係
}

\author{
福田 匡 ${ }^{* 1}$ ，森本 隆司 ${ }^{* 2}$ ，演端 直人*3
}

\section{Relation between jet flow energy and pulverization work in gas atomization process}

\author{
Tadashi FUKUDA $^{* 1}$, Ryuji MORIMOTO ${ }^{* 2}$ and Naoto HAMABATA ${ }^{* 3}$ \\ ${ }^{* 1,}{ }_{2},{ }^{*} 3$ National Institute of Technology, Wakayama College Dept. of Advanced Mechanical Engineering \\ 77 Noshima, Nada-cho, Gobo-city, Wakayama 644-0023, Japan
}

Received 27 August 2014

\begin{abstract}
The relationship between the kinetic energy of spraying medium and pulverization work for forming powder using molten metal in gas atomization process has been experimentally studied, which intends improvements of manufacturing fine powder in atomization process. Compressed air was ejected through 1.0, 1.2, $1.5 \mathrm{~mm}$ diameter 6 nozzles forming a reverse conical jet whose apex angle is 30 or 40 degrees. The velocity distribution of the gas jet is measured using Pitot tube attached to a traversing equipment. The kinetic energy and momentum of the gas jet were calculated based on measurements of the gas velocity distribution. The gas jet power at the horizontal plane including the geometrical focus was about $15 \sim 25 \%$ of the compressing power and it decreases in downstream direction. With the molten metal tube fitted into the atomizing nozzle, molten tin was poured into the gas jets and the powders were produced by gas atomization. The distribution of the particle size was measured by sieving. Median diameters of the powders decreased in accordance with the gas jet power, though they exhibited a lower limit value in higher power region. The surface energy of the powder which is regarded as the pulverization work was obtained by multiplying the powder surface and the surface tension for each particle size section. The pulverization work to form powder is as small as about $1 / 1000$ of the jet flow energy.
\end{abstract}

Key words : Atomization, Powder metallurgy, Pulverization, Atomizing nozzle, Gas jet, Kinetic energy, Molten metal

\section{1. 緒言}

粉末治金製品は機械部品を中心に各種の機器に使われている.その原材料として国内では年間約 15 万トンの鉄 系粉末が出荷されており，海外での流通量はその 3 倍程度と言われている(日本粉末治金工業会，2013). 鉄系粉 末の製造には主に水アトマイズ法が用いられ(河合他，2000)，また高合金粉末の製造にはガスアトマイズ法が用 いられることが多い. 圧粉体の焼結性を向上させ，微細形状品を成形寸る観点から微粉末の適用が志向される. アトマイズ法での微粉末生成に際して, 経験的に高圧・大流量の噴霧媒を噴射することが行われており, 噴射装 置が溶融金属で閉塞するなどの操業トラブルが発生しやすい. また, 高速の噴霧媒を溶融材料に衝突させて粉砕, 冷却する過程のエネルギー利用率が低いことは概括的に示されている（永井, 1993）（Yule and Dunkley, 1994）が， 噴射エネルギーが粉砕仕事に変換される各過程でエネルギーの変換率を定量的に把握することが必要と考えられ

No. 14-00434 [DOI: 10.1299/transjsme.2014fe0320]

${ }^{* 1}$ 正員, 和歌山工業高等専門学校 知能機械工学科（产644-0023 和歌山県御坊市名田町野島 77)

*2 和歌山工業高等専門学校 専攻科 (現 三浦工業(株) 北四国支社)

*3 和歌山工業高等専門学校 専攻科（現富士ゼロックスアドバンストテクノロジー(株))

E-mail of corresponding author:fukuda@wakayama-nct.ac.jp 
る. 金属材料の噴霧条件と生成粉末粒度の関係は実験的に知られている（Lubanska，1970）(福田，阿佐部，1999） が，エネルギー利用率を高める観点からの検討はほとんど見当たらない. このようなことから, 効率的な粉砕を 行うための適切な噴霧方法を検討して微粉末の生成効率を高めることが求められる.

そこで本研究では噴流場の運動エネルギーならびに試作粉末の粒度から推定した粉砕仕事から, 噴流の運動エ ネルギーが溶融材料の粉砕仕事に変換される過程のエネルギー効率について検討を加える.

\section{2. 記 号}

\begin{tabular}{|c|c|c|}
\hline$d$ & : 噴射孔(直円管)の内径 & {$[\mathrm{mm}]$} \\
\hline$D$ & : 噴射孔の出口中心を連ねた設置円の径 & {$[\mathrm{mm}]$} \\
\hline$G$ & : ガスの質量流量 & {$[\mathrm{kg} / \mathrm{s}]$} \\
\hline$L$ & : 噴射孔設置円の中心と溶湯管出口端との垂直距離 & [m] \\
\hline$M$ & : マッハ数 & {$[-]$} \\
\hline$M_{1}$ & : 衝撃波上流でのマッハ数 & {$[-]$} \\
\hline$n$ & : 噴射孔の数 & {$[-]$} \\
\hline$P_{C}$ & : コンプレッサでの圧縮動力 & {$[\mathrm{W}]$} \\
\hline$P_{J}$ & : ある断面での噴流全体の単位時間当たり 運動エネルギー & {$[\mathrm{W}]$} \\
\hline$P_{S}$ & : 粉末表面エネルギーの単位時間当たり生成量 & {$[\mathrm{W}]$} \\
\hline$p$ & : ガスの噴射圧力（静圧） & {$[\mathrm{Pa}]$} \\
\hline$p_{0}$ & : 全圧 & {$[\mathrm{Pa}]$} \\
\hline$p_{01}$ & : 衝撃波上流の全圧 & {$[\mathrm{Pa}]$} \\
\hline$p_{02}$ & : 衝撃波下流の全圧 & {$[\mathrm{Pa}]$} \\
\hline$p_{a}$ & : 圧縮前のガス圧力（静圧） & {$[\mathrm{Pa}]$} \\
\hline$p_{b}$ & : 圧縮後のガス圧力（静圧） & {$[\mathrm{Pa}]$} \\
\hline$p_{s}$ & : 静圧 & {$[\mathrm{Pa}]$} \\
\hline$p_{s l}$ & : 衝撃波上流の静圧 & {$[\mathrm{Pa}]$} \\
\hline$r_{0}$ & : 噴流の半径 & {$[\mathrm{m}]$} \\
\hline$R$ & : ガス定数 & {$[\mathrm{J} /(\mathrm{kg} \cdot \mathrm{K})]$} \\
\hline$T_{0}$ & : 貯気槽温度 & {$[\mathrm{K}]$} \\
\hline$T_{a}$ & : 圧縮前の空気温度 & {$[\mathrm{K}]$} \\
\hline$v_{z}$ & : ガスの鉛直下向き流速 & {$[\mathrm{m} / \mathrm{s}]$} \\
\hline$\Delta p_{m}$ & : 溶湯管出口の圧力（ゲージ圧） & {$[\mathrm{kPa}-$ Gauge $]$} \\
\hline$\kappa$ & $:$ 比熱比 & {$[-]$} \\
\hline$\theta$ & : 噴射孔軸芯の交差角度（噴射頂角） & {$\left[{ }^{\circ}\right]$} \\
\hline
\end{tabular}

\section{3. 実験装置および方法}

ガスアトマイズ法に用いる空気噴流の流速分布の測定ならびに粉末の試作を次のように行った.

\section{$3 \cdot 1$ 空気噴流の生成}

実験装置の概略を図 1 に示寸. 冷凍式脱湿装置を備えたコンプレッサにて約 $0.8 \mathrm{MPa}$ の圧縮空気を生成し，浮 子式流量計，圧力計，温度計を通して図 2 に断面を示寸噴射治具に所定圧力の空気を供給して噴射した．噴射治 具は鋼構造物に固定し，図 1 の破線内に示すトラバーサに固定したピトー管を噴射治具の下部に設置し，空気噴 流のみを下向きに射出した状態でピトー管を用いて噴流の流速を測定した. 粉末生成時は, 一辺 $495 \mathrm{~mm}$ で高さ $1000 \mathrm{~mm}$ の矩形タンクの出口にバグフィルタを装着し，タンク上部に前記の噴射治具を設置した．噴射治具中央 部の開口に溶湯管を挿入して溶融金属を流下させ，空気噴流で粉砕・冷却し，バグフィルタに生成粉末を回収し た. 
噴射治具は図 2 に示寸ように，中央部に溶湯管を通寸貫通口を有し，これを取り囲む 6 個の噴射孔から圧縮空 気を噴射した．噴射孔は同一円周上に等間隔に 6 個設け，内径 $d$ が $1.0 \sim 1.5 \mathrm{~mm}$ の直円管で，軸芯の交差角すな わち噴射頂角 $\theta$ は $30^{\circ}$ あるいは $40^{\circ}$ とした. シュリーレン写真などから，6個の噴流は逆円錐形を形成したのち 合流してほぼ鉛直下向きに流れることが観察された. 実験に供した噴射治具の諸元を表 1 に示す。ここで $D$ は噴 射孔の出口中心を連㸚た設置円の径である.

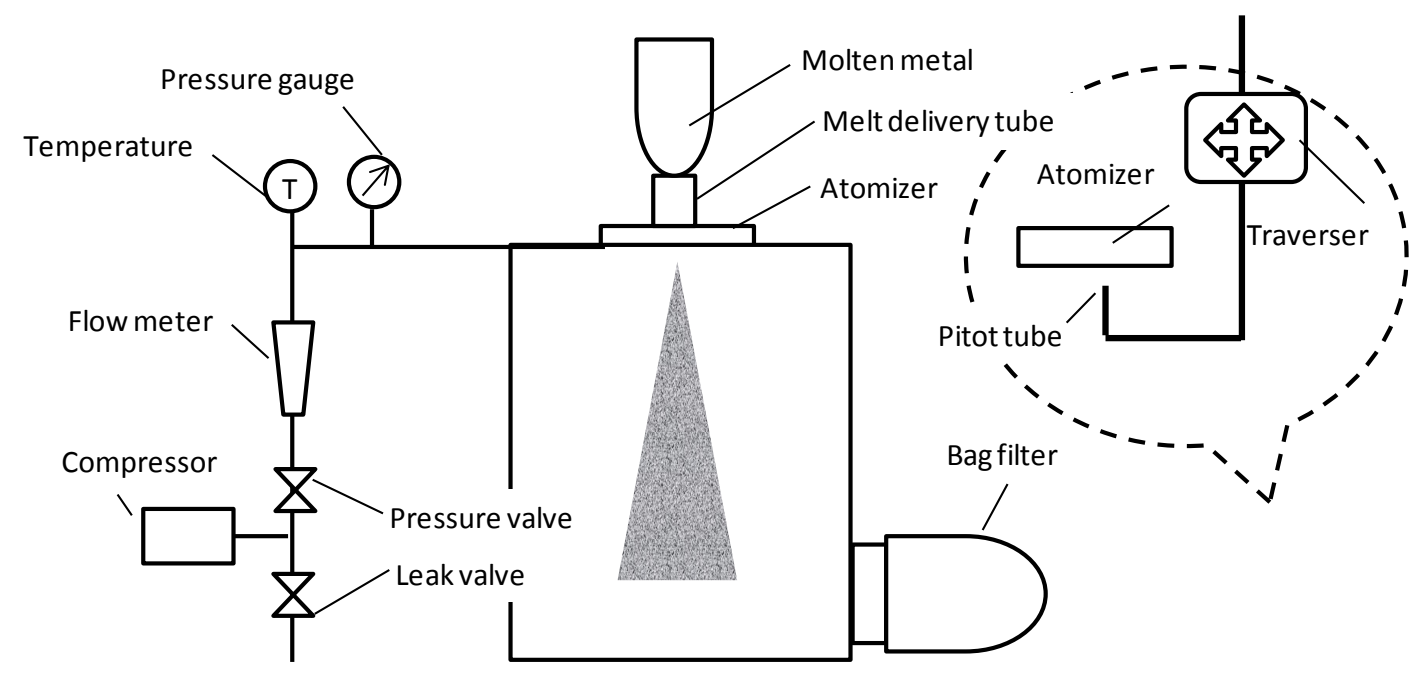

Fig.1 Layout of experimental apparatus

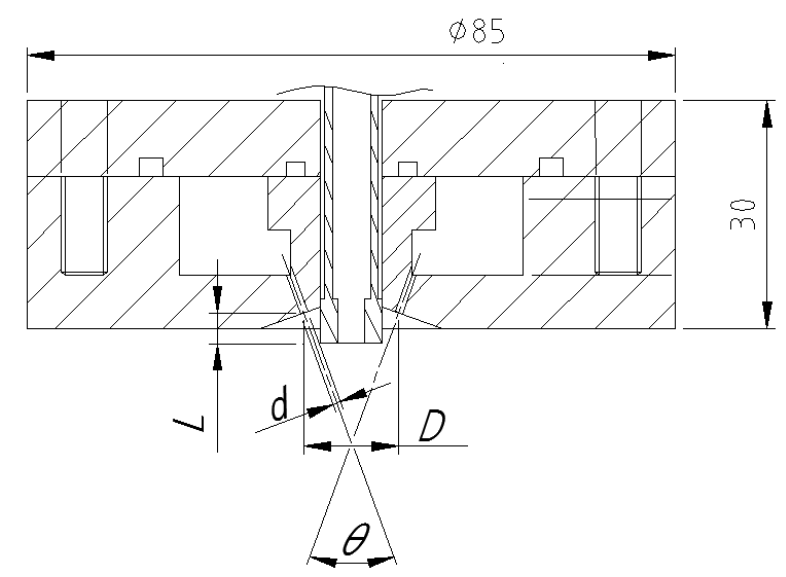

Table 1 Specification of test nozzles

Fig.2 Configuration of atomizing nozzle

\section{$3 \cdot 2$ 噴流の流速分布測定および運動エネルギ一の算定}

噴流中の所定位置に鼻管の外径と長さがそれぞれ $1.0 \mathrm{~mm}$ と $14 \mathrm{~mm}$ のピトー管を置き，全圧を測定して流速を 求めた．流れが亜音速の場合は式 (1) と式 (2) から流速 $v$ を求めた. 流れが超音速の場合, プローブ前方に離脱 衝撃波ができるので Rayleigh のピト一管公式が適用できるとして式 (1) と式 (3) から流速 $v$ を求めた（生井，松 尾，1977）。なお，衝撃波上流の静圧 $p s_{1}$ は代表的な噴射条件において静圧プローブを用いて測定したところ大気 圧にほぼ等しかったので全ての条件で大気圧とみなした.

$$
v=M\left(\kappa R T_{0}\right)^{\frac{1}{2}}\left(1+\frac{\kappa-1}{2} M^{2}\right)^{-\frac{1}{2}}
$$


亜音速 $(M<1)$ の場合

$$
\frac{p_{0}}{p_{s}}=\left(1+\frac{\kappa-1}{2} M^{2}\right)^{\frac{\kappa}{\kappa-1}}
$$

超音速 $(M \geqq 1)$ の場合

$$
\frac{p_{02}}{p_{s 1}}=\frac{p_{02}}{p_{01}} \frac{p_{01}}{p_{s 1}}=\left\{\frac{(\kappa+1) M_{1}^{2}}{2}\right\}^{\frac{\kappa}{\kappa-1}}\left\{\frac{\kappa+1}{2 \kappa M_{1}^{2}-(\kappa-1)}\right\}^{\frac{1}{\kappa-1}}
$$

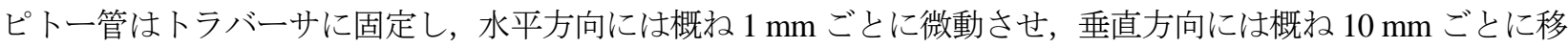
動させて全圧を測定した.

\section{3 -3 粉末生成および表面エネルギ一の算定}

粉末の生成は試料に純錫を用い，融点より約 $50{ }^{\circ} \mathrm{C}$ 高温の溶融錫を予熱した溶湯容器に流し入れ，溶湯管から 流下させ，予め所定の条件で噴射してある空気噴流によって粉砕・冷却して粉末を生成した．なお，溶湯容器に 供給した溶融錫は全量が流出して噴霧された。

粉末の生成にあたり，溶湯管の先端部に設けた熱電対で温度を測定し，その指示值変化から溶融錫の流出開始 と終了を検知して溶融錫の噴霧時間を求めた。

生成した粉末を回収し，目開き $20 \mu \mathrm{m} \sim 250 \mu \mathrm{m}$ の 8 個の JIS 標準篩を用いて分級した. 生成粒子は球形と仮定 し，各粒度区分の粉末粒子径が篩目開きの平均值に等しいとして計算した個数に球形粒子の表面積を乗じ，これ に温度 $600 \mathrm{~K}$ での錫の表面張力 $0.558 \mathrm{~N} / \mathrm{m}$ （日本機械学会編，1987）を乗じて表面エネルギーを求めた. このよう にして求めた表面エネルギーが粉砕仕事に等しいとした.

\section{4. 実験結果および考察}

\section{$4 \cdot 1$ 溶湯管出口部の圧力と突き出し長の関係}

溶融金属を安定して噴霧するには溶湯管の出口部が負圧であることが必要と分かっている（福田他,1996）。図 2 中に $L$ で表記した，噴射孔設置円の中心と溶湯管出口端との垂直距離である突き出し長を変えて，所定圧力で噴 射し，溶湯管の他端を封じて設けた圧力計によって溶湯管出口部の圧力を測定した. 図 3 に測定結果を示すよう に，突き出し長 $L$ を増すに従って溶湯管出口部の負圧が増大していき，ある $L$ 值以上で負圧の值は飽和し，噴射

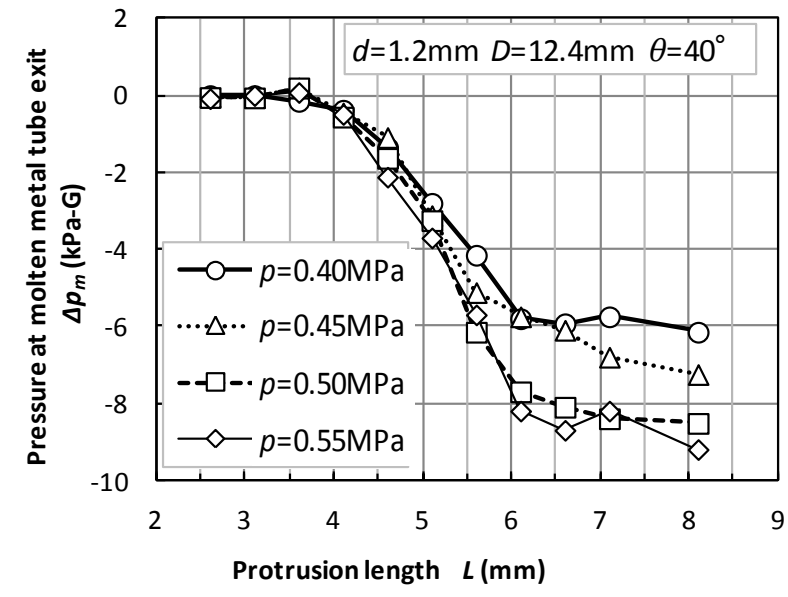

Fig.3 An example of pressure changes at the molten metal tube exit corresponding to the protrusion length. Negative pressure at molten metal tube exit increases as the protrusion length increases and saturates beyond $L$ is larger than $6 \mathrm{~mm}$. Larger negative pressure appears when higher pressure gas is sprayed.

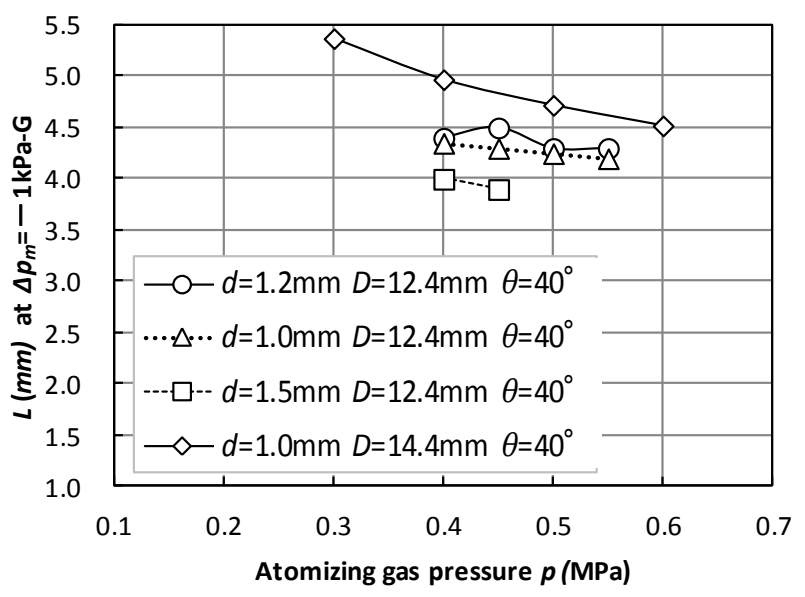

Fig.4 Protrusion length corresponding to $\Delta p_{m} \fallingdotseq-1 \mathrm{kPa}-$ Gauge which enables both free blowup and high velocity atomizing. 
圧力が大きいほど増大した．このように $L$ を増すと負圧が増す特性は噴射角度あるいは噴射孔の設置円径を変え ても同様であった．いっぽう後述の図 5(b)に示すとおり $L$ を増すと空気噴流が溶湯管に衝突する割合が増えて噴 流の流速が低下寸るので，溶湯管出口を負圧に保って，噴霧媒の流速減衰が小さくなるように溶湯管出口部の今゙ ージ圧 $\Delta p_{m}$ が約一 $1 \mathrm{kPa}$ となるように溶湯管を配置して噴流の流速測定ならびに粉末生成を行った. 図 4 に示寸 ように $\Delta p_{m}$ が約一 $1 \mathrm{kPa}$ となる突き出し長は，噴射圧が高いほど，また噴射孔径が大きいほど，そして噴射孔が 近接しているほど短くなった.

\section{4－2 空気噴流の流速分布}

噴射治具から圧縮空気のみを噴射して，空気噴流の鉛直下向き方向の流速を測定した．噴射孔の設置円の中心 を原点として，鉛直下向きに $z$ 座標をとり,$z$ 軸と直交する水平面上でほぼ直交する 2 つ直径方向（ $r$ 方向）で ピト一管を移動させて鉛直方向の空気流速 $v_{z}$ を測定した．垂直位置 $z$ を変えて同様の測定を行ない，次に噴射圧 力が異なる場合について同様に測定した．なお，流速の測定は溶湯管を所定の突き出し長となるように噴射治具 に固定した状態で行った.

噴射孔径 $d=1.0 \mathrm{~mm}$, 噴射孔設置円径 $D=12.4 \mathrm{~mm}$, 噴射頂角 $\theta=40^{\circ}$ ，噴射圧 $p=0.4 \mathrm{MPa}$ ，垂直位置 $z=27.1 \mathrm{~mm}$ （幾何焦点の $10 \mathrm{~mm}$ 下方）で測定した流速分布を図 5(a)に示す. 流速分布は中心点 $(r=0)$ で最大值を示して概ね凸 形であった．また異なる $r$ 方向の流速分布もおおむ称同じ測定值であったので，両者を平均して該当の $r$ 位置の 流速とした. $r$ 方向の流速分布から 6 個の噴射孔から射出された空気噴流は合流して一体化していると見なせた.

次に $d=1.2 \mathrm{~mm}, D=12.4 \mathrm{~mm}, \theta=40^{\circ}, p=0.5 \mathrm{MPa}, z=17.1 \mathrm{~mm}$ (幾何焦点) において, 溶湯管突出し長 $L$ 異 なる場合の流速分布を図 5(b)に示す. 溶湯管端部が噴射孔の軸芯に接する位置まで突き出して, $L=6.1 \mathrm{~mm}$ とした 場合は噴流の流速が大きく減衰した。 このとき溶湯管出口部で $\Delta p_{m}=-7.7 \mathrm{kPa}-\mathrm{G}$ と基準より大きな負圧が生じて いた.

幾何焦点での流速は，噴射圧力が高いほど，噴射頂角が大きいほど，噴射孔の設置円径が小さくて噴射孔と幾 何焦点が近接するほど高い值を示した．また噴流中心流速の下流方向での減衰および噴流域の広がりは比較的少 なかった．噴流のパワー（単位時間あたりの運動エネルギー）の下流方向の変化については 4.4 節に述べる.

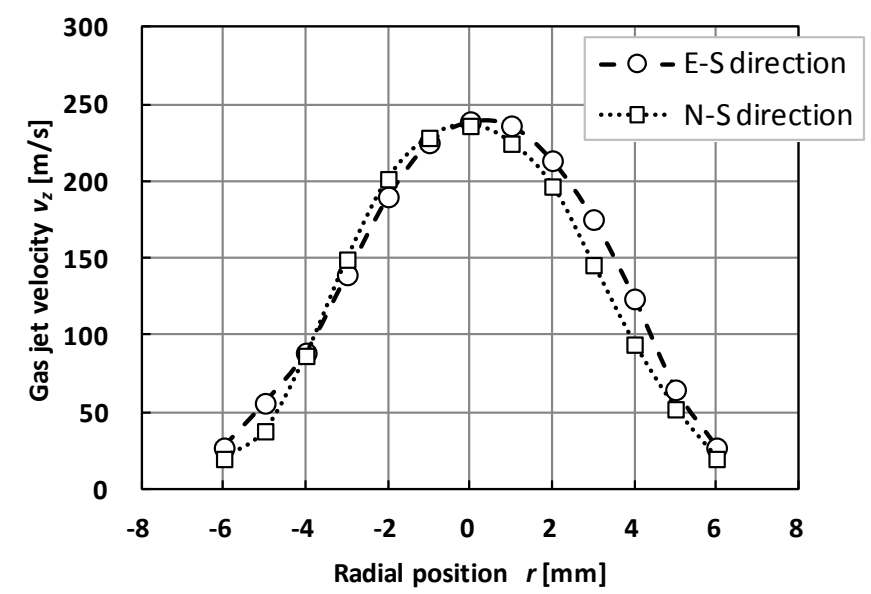

(a) Gas jet velocity distribution is symmetric with respect to $\mathrm{z}$-axis and shows a concave profile. Gas velocity indicates almost the same values at the same $\mathrm{r}$-coordinate in different directions.

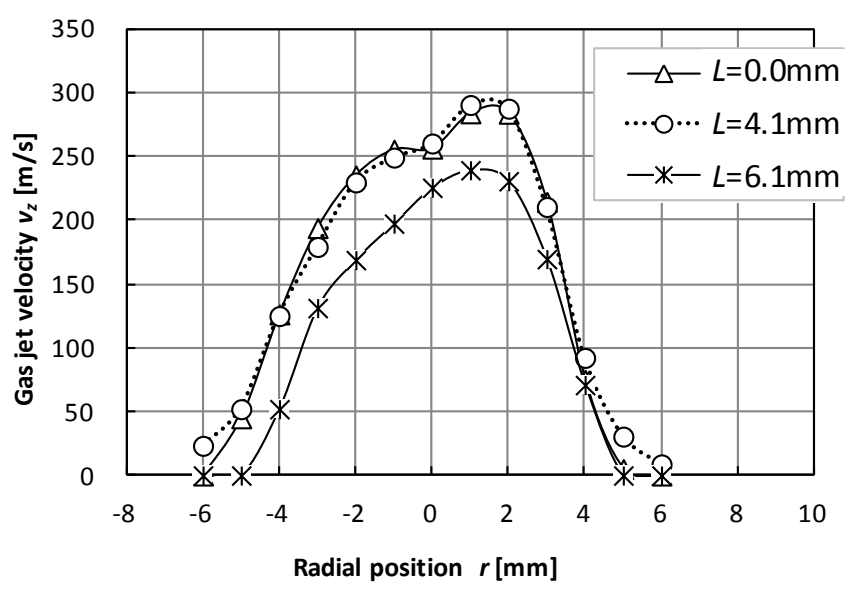

(b) Gas jet velocity decreases severely when molten metal tube interferes the gas jet flow.

Fig.5 An example of gas velocity distribution in a certain horizontal plane 


\section{$4 \cdot 3$ 噴流の運動量}

供試噴射治具によって生成される噴流の特性を検討するため, 流れ方向の運動量変化を調べた. 種々の噴射条 件において空気噴流の流速分布を測定し，微小な円環部を通過する空気噴流の単位時間の運動量を密度 $\rho$ と流速 $v_{z}$ から求め, 式 (4) に示すとおり該当の水平面で積算して, 各水平面を通過する噴流の単位時間運動量すなわち 垂直方向に作用する力を求めた．各垂直位置の単位時間運動量 $\dot{M}(z)$ を算定した結果を図 6 に示す.

$$
\dot{M}(z)=\int_{A} v_{z} \cdot d G=\int_{0}^{r_{o}} v_{z} \cdot \rho v_{z} \cdot 2 \pi r d r=2 \pi \rho \int_{0}^{r_{o}} v_{z}^{2} r d r
$$

図 6 に示すように, $z=12.1$ 47.1 mm の各水平面において噴流の運動量は下流に進むほどわずかに減少した. 二 次元乱流自由噴流については噴流軸に直角な断面を通過する運動量は一定として解析されている(社河内, 2004). 同様の結果が本研究に用いた合流噴流について測定された.

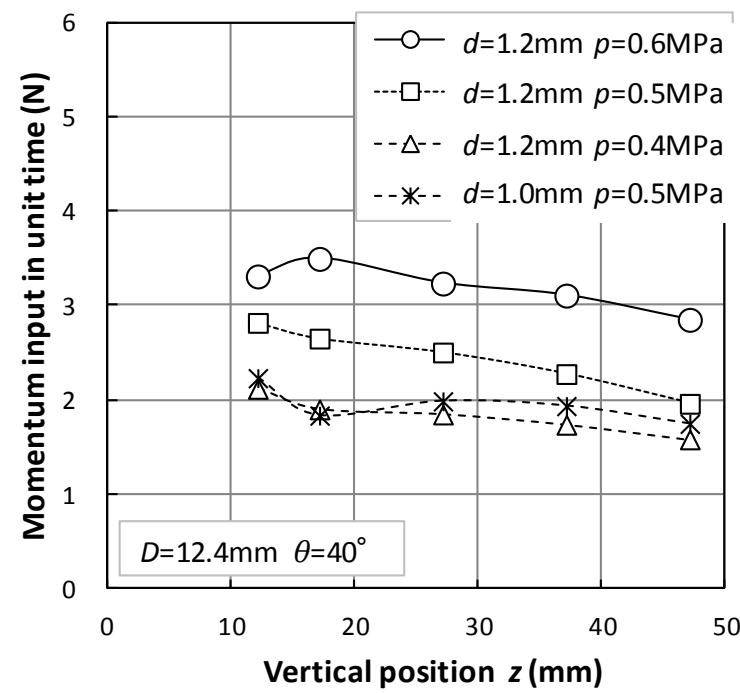

Fig.6 Input of gas jet momentum in unit time. Vertical momentum input in unit time for gas jets, or vertical force exerted by gas jets, slightly decreases downstream.

\section{$4 \cdot 4$ 噴流の運動エネルギー}

生成した空気噴流について噴流域を多数の円環に区分し，各円環部を通過する空気噴流の流速 $v$ と密度 $\rho$ 用 いて単位時間当たり運動エネルギーを求め, 式 (5) に示すように該当の水平面で積算して断面を通過する噴流全 体の単位時間あたり運動エネルギー（噴流パワー） $P_{J}(z)$ を求めた.

$$
P_{J}(z)=\int_{A} \frac{1}{2} v_{z}^{2} \cdot d G=\int_{0}^{r_{0}} \frac{1}{2} v_{z}^{2} \cdot \rho v_{z} \cdot 2 \pi r d r=\pi \rho \int_{0}^{r_{o}} v_{z}^{3} r d r
$$

噴射孔径 $d=1.2 \mathrm{~mm}$, 噴射孔設置円径 $D=12.4 \mathrm{~mm}$, 噴射頂角 $\theta=40^{\circ}$ の噴射治具を用い, 噴射圧力 $p$ が $0.4 \sim 0.6 \mathrm{MPa}$ の場合の流速測定結果から噴流パワー $P_{J}(z)$ を算定した結果を図 7(a)に示寸. 噴流パワーは，噴射圧力が増すほど 大きくなり，噴射孔からの距離が増すと減衰した.

噴流パワーに与える突き出し長 $L$ の影響は大きく, 図 7(b)に示すように $d=1.2 \mathrm{~mm}, D=12.4 \mathrm{~mm}, \theta=40^{\circ}$ ， $p=0.5 \mathrm{MPa}$ の場合, 噴流が溶湯管端部に干渉されない $L=4.1 \mathrm{~mm}$ の場合に比べて, 噴射孔の軸芯延長線が溶湯管 端部に接する $L=6.1 \mathrm{~mm}$ の場合には噴流パワーがほぼ半減した。なお，噴射孔径が異なる場合に， $D=12.4 \mathrm{~mm}$ ， 
$\theta=40^{\circ}$ において $d=1.2 \mathrm{~mm}, p=0.5 \mathrm{MPa}$ と $d=1.5 \mathrm{~mm}, p=0.4 \mathrm{MPa}$ の場合を比較して分かるように両者の噴射流量 が $0.0063 \mathrm{~kg} / \mathrm{s}$ と $0.0071 \mathrm{~kg} / \mathrm{s}$ のように概ね同じであると噴流パワーはほぼ同じ值が得られた.

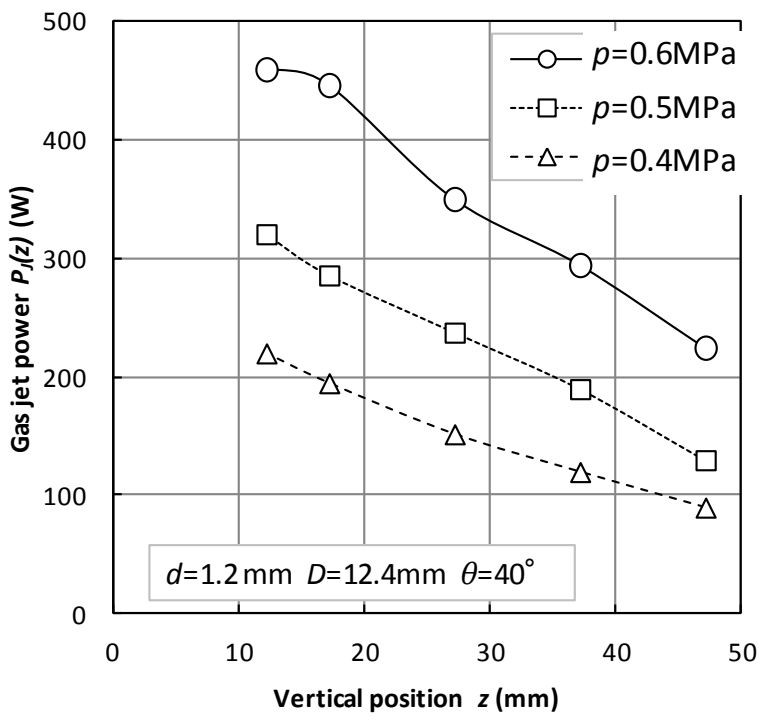

(a) Gas jet power decreases in the downstream direction. Higher gas jet power is obtained when higher pressure gas is sprayed through the same atomizing nozzle.

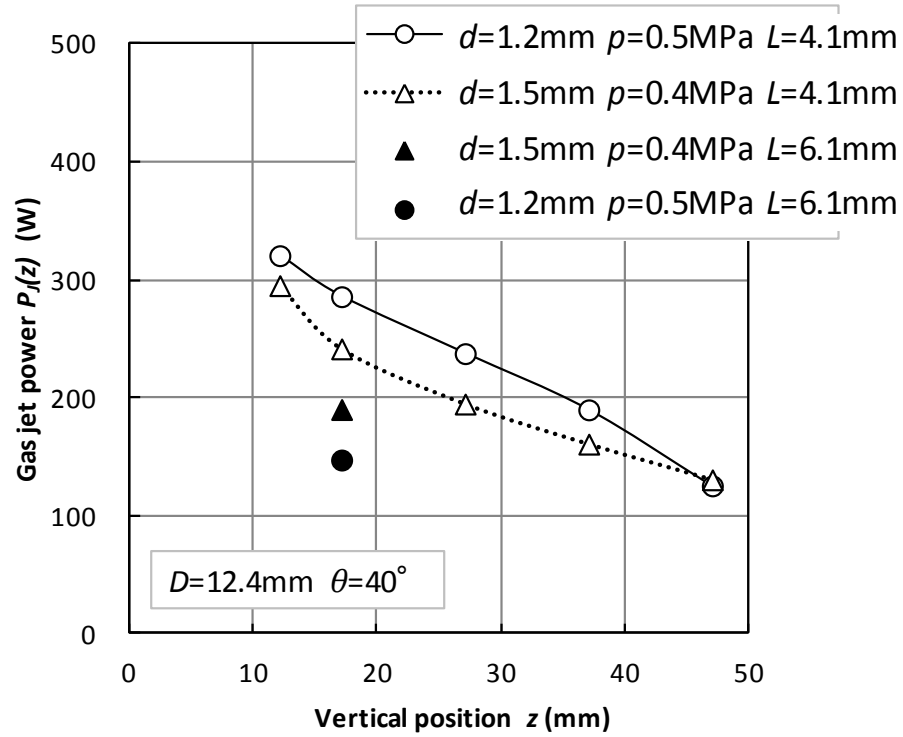

(b) Gas jet power decreases severely when $L$ is enlarged. Similar gas jet power is obtained when the gas of the same mass flow rate is sprayed.

Fig.7 An example of change for gas jet power in the downstream direction.

次に, コンプレッサで空気が断熱圧縮されるとし，工業仕事に空気流量を乗じて圧縮空気流を生成する動力 $P_{C}$ を式 (6) で求めた。噴流のパワー $P_{J}(z)$ を圧縮動力 $P_{C}$ で除して, 噴流の下流方向の減衰を各条件で比較して図 8 に示す. 圧縮動力 $P_{C}$ に対する比率 $P_{J}(z) / P_{C}$ は噴流の下流ほど減少し, 幾何焦点での比率は噴射孔設置円径 $D=12.4 \mathrm{~mm}$ の場合に約 $25 \%, D=14.4 \mathrm{~mm}$ の場合は約 $15 \%$ であった. 噴流は周囲気体を巻き込んで流量は下流ほど 増すが，減速するため運動エネルギーは減衰して周囲に散逸していく．溶融材料の粉砕が行われると考えられる 幾何焦点近傍の噴流パワーは圧縮空気を生成する動力の約 15～25\%になっていたと推定される.

$$
P_{C}=G \frac{\kappa R}{\kappa-1} T_{a}\left\{\left(\frac{p_{a}}{p_{b}}\right)^{\frac{1-\kappa}{\kappa}}-1\right\}
$$

\section{4５５試作粉末の粒度および表面エネルギー}

$d=1.2 \mathrm{~mm}, \quad D=12.4 \mathrm{~mm}, \quad \theta=40^{\circ}$ の噴射治具を用い，噴射圧力を変更して溶融錫を噴霧して得た粉末の粒度分 布を図 9 に示すメジアン径は噴霧媒の噴射圧が高いほど減少した．また，噴射圧力が異なっても流量がほぼ同 じである $d=1.2 \mathrm{~mm}, p=0.6 \mathrm{MPa}$ と $d=1.5 \mathrm{~mm}, p=0.4 \mathrm{MPa}$ の場合に生成する粉末の粒度は同等であった.

表 1 に示寸噴射治具を用い，異なる噴霧条件で錫粉末を生成して粒度分布を測定した. 図 10 にメジアン径と幾 何焦点における噴流パワーの関係を示す.メジアン径は噴流パワーが増すほど小さくなるが，本実験条件では下 限值（約 $70 \mu \mathrm{m}$ ）を有する傾向ならびに噴射治具の $D$ が小さい近接噴射を行った場合に同じ噴流パワーに対して メジアン径の大きい粉末を生成する傾向を示した. 溶融材料は噴流が生成する逆円錐形の負圧域に吸入されるが, 噴流の合流域に生じる上向きの逆流はガス流速が大きいほど強くなるため, 溶融材料の一部が吹き上げられて有 効に粉砕されないことが原因の一つと考えられる. 


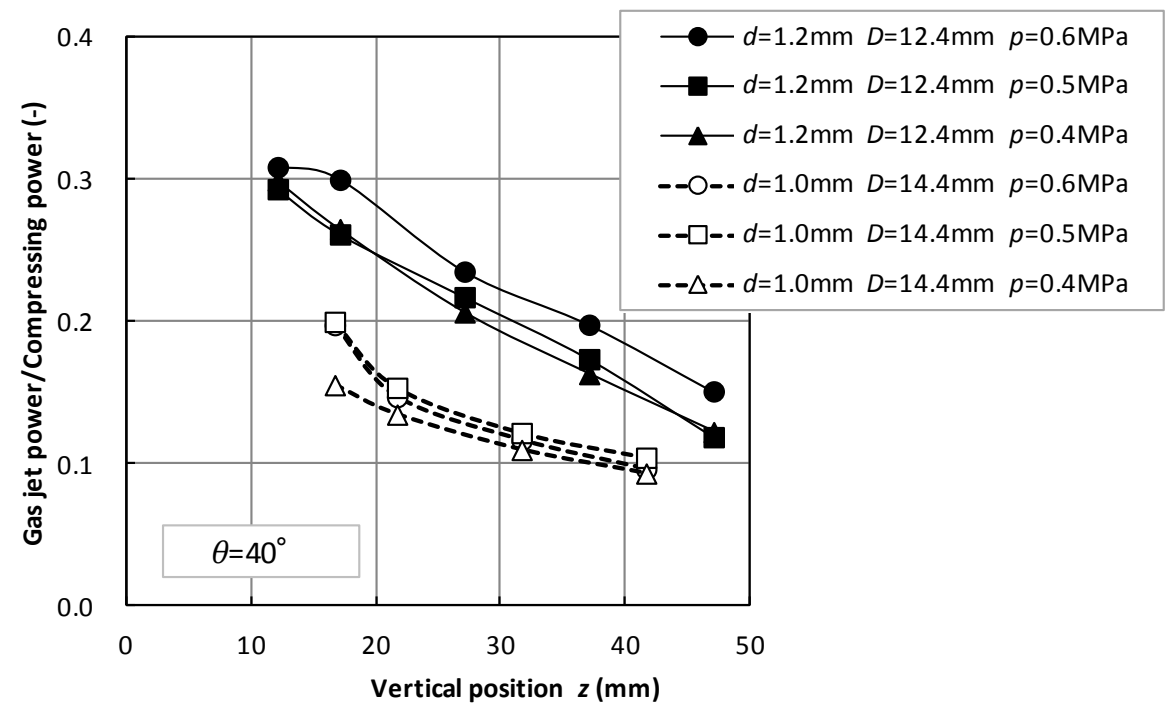

Fig.8 The ratio of gas jet power to the compressing one. $P_{J} / P_{C}$ decreases in the downstream direction, it slightly increases when the gas holes become closer and when higher pressure gas is sprayed.

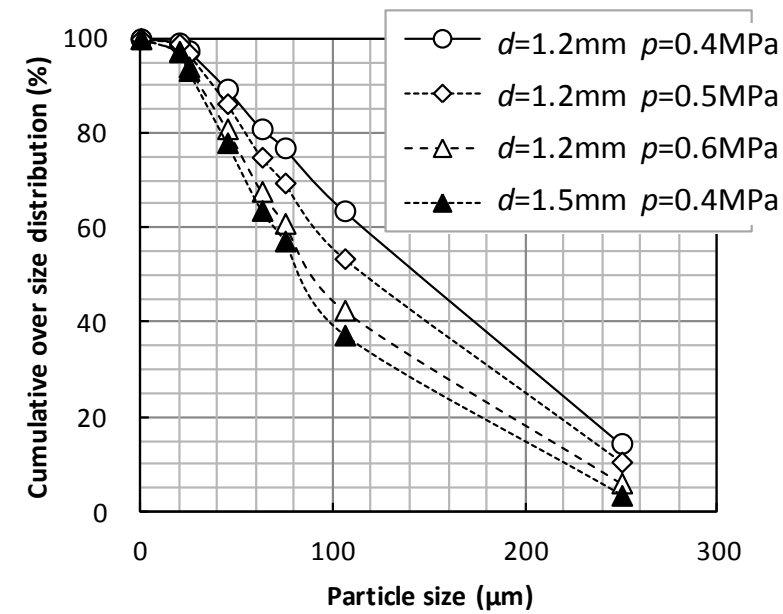

Fig.9 An example of particle size distribution produced by gas atomization. Finer particles are obtained when higher pressure gas is sprayed, and similar size distribution is obtained when the same flow rate of gas is sprayed.

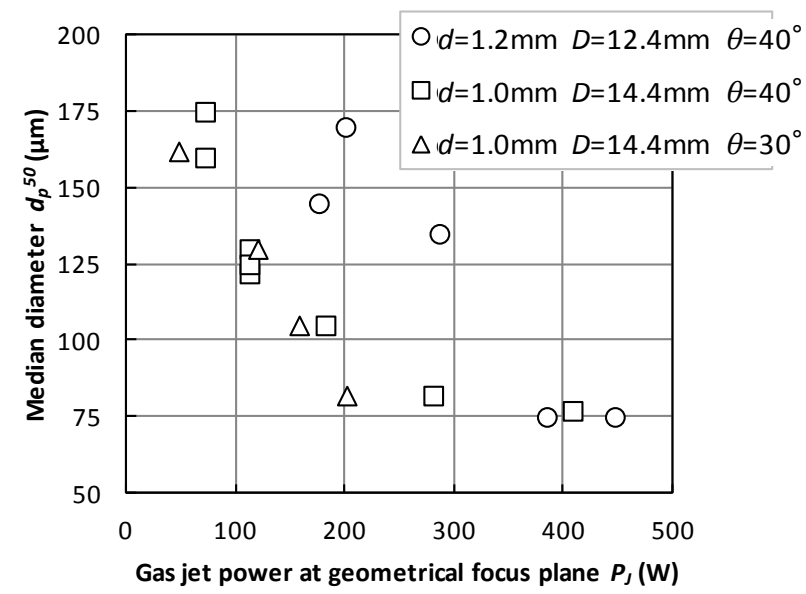

Fig.10 Relation between median diameter of the powder and the gas jet power passing through the horizontal plane located at the geometrical focus. Median diameter decreases as gas jet power increases while decrease in median diameter is saturated at about $70 \mu \mathrm{m}$.

\section{4-6 噴流による溶融材料粉䂶過程のエネルギ一変換}

生成粉末について，各分級範囲の中央值が球形粒子の代表径として，回収質量から粒子個数を計算するととも に，粒子の表面積に純錫の表面張力を乗じて表面エネルギー量を求め，粒子個数と表面エネルギーを乗じて噴霧 時間で除して, 全粒度区分での值を積算して単位時間の粉末表面エネルギー生成量 $P_{S}$ を求めた. 粉末生成時と同 
条件で空気噴射のみ行って測定した幾何焦点における噴流パワーと比較した結果を図 11 に示す. なお溶融錫の表 面張力は酸化により多少小さくなると推定されるが，純錫の物性值を用いて実験試料の粉末表面エネルギーとし ては多少大きな值を算定したと考えられる.

単位時間あたりの粉末表面エネルギー生成量は噴流パワーに比べて小さく, 溶融材料に加えられた粉砕仕事は 噴流の運動エネルギーのきわめて小さい部分であると考えられる.図 10 に示すように生成粉末粒度と噴流パワー の間に相関は認められるが, 図 11 に示すようにエネルギー量に $10^{3}$ 倍程度の差異がある. 粉砕途中では複雑形状 に変形して表面エネルギーが大きい状態から表面張力によって球形になって固化するため粉砕エネルギー量を小 さく算定してしまうことが一因と考えられるが，両者の大きな差異の原因は明らかではない. 4・4 節に示したよ うに圧縮動力から噴流パワーへの変換率が 15〜25\%になると分かったが, 粉砕効率は $0.04 \sim 0.1 \%$ ときわめて小さ い值を得るに止まったので溶融材料の分裂に対寸る噴流仕様の影響を解明することが必要である.

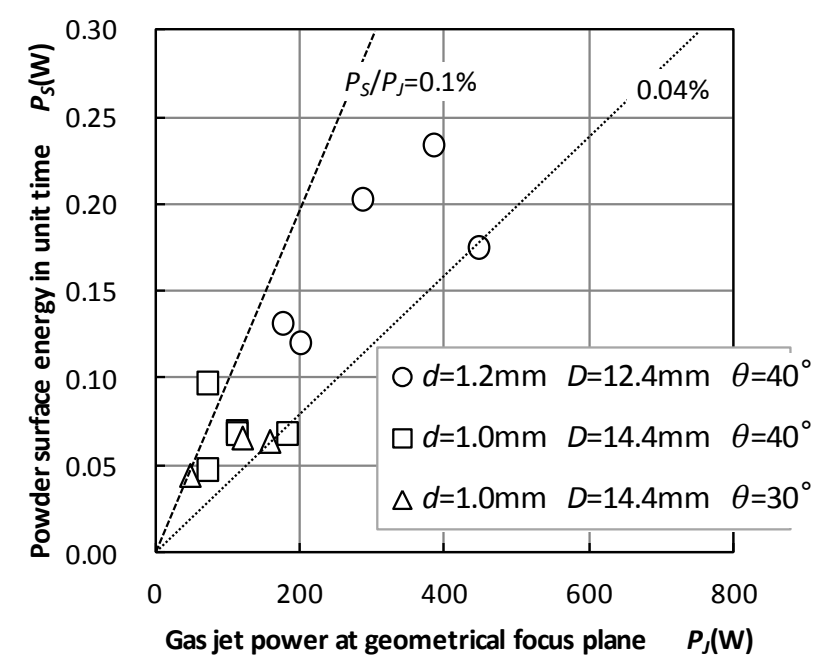

Fig.11 Relation between powder surface energy in unit time and the gas jet power passing through the horizontal plane located at the geometrical focus. Powder surface energy to be regarded as pulverization work shows very small value compared to the gas jet energy.

なお，本実験条件では噴霧媒である圧縮空気と溶融材料の質量流量比は $1: 5$ 程度であるから，アトマイズ粉末 の飛行速度に関する従来結果（稲村，永井，1991）（Krauss, et al., 2002）から，噴霧粒子の速度を $60 \mathrm{~m} / \mathrm{s}$ 程度すな わち噴射孔でのガス噴流の $1 / 5$ 程度まで加速されると仮定して, 噴流エネルギーの $20 \%$ 程度が粒子の加速に費や されると考えられる．また噴射ガスは周囲流体を巻き込んで減速し噴射孔から約 $100 \mathrm{~mm}$ 下流において，噴流の 流量は噴射流量の 3 倍程度, 平均流速は噴射孔でのガス噴流の $1 / 5$ 程度になることから, 噴流エネルギーの $10 \%$ 程度が周囲流体の加速に費やされると考えられる．両者を合わせて噴射空気の運動エネルギーの約 30\%は粉末と 周囲流体の加速に費やされ，アトマイズタンク内で粉末とタンク内の気体を流動させて，生成粉末を急冷するこ とに費やされると考えられる。噴流の運動エネルギーの残部は溶湯管との衝突, 溶融材料の粉砕, 器壁との衝突 や噴流内の渦生成などにより散逸すると推定される.

\section{5. 結}

本研究ではガスアトマイズ法において，噴霧媒の運動エネルギーが溶融材料を粉砕するエネルギーに変換され る過程を検討して，粉末生成の粉砕仕事と噴流の運動エネルギーの関係を明らかにすることを目的として，複数 
の噴流を逆円錐形に形成して合流させた空気噴流の流速測定と溶融錫を噴霧して粉末を生成する実験を行った結 果, 次の結論を得た.

1. 合流噴流の水平面における流速分布は幾何焦点より下流で凸形であった. 流速は下流方向に進むに従ってわ ずかに減少し，噴流域の広がりは少なかった。

2. 溶湯管の突き出し長を増すほど，溶湯管出口の負圧が増した．溶湯管が合流前の各噴流に干渉する位置まで 突き出した場合，噴流の流速は大きく減衰した，溶融材料の噴霧は流速減衰が軽微となる溶湯管突き出し長にて 行うことができた.

3. 合流噴流のパワー（単位時間の運動エネルギー）は噴射圧力と流量に応じて変化し, 下流方向に減少した. 噴流パワー $P_{J}$ と圧縮動力 $P_{C}$ の比は同一諸元の噴射治具では一定の関係となった. 幾何焦点での $P_{J} / P_{C}$ は 15 25\% であった.

4. 生成粉末のメジアン径は幾何焦点における噴流パワーと相関を示したが，約 $70 \mu \mathrm{m}$ を下限として飽和する 傾向を示した.

5. 粉末の表面エネルギーが粉砕仕事に等しいとすれば, 噴流パワーに対する粉砕仕事率は千分の一程度と極め て小さい比率であることが分かった。

\section{文献}

福田匡, 中西睦夫, 久保敏彦, コンファインド型ガスアトマイズノズルにおける溶湯管周辺の圧力分布, 鉄と鋼, Vol.82, No.8 (1996), pp.665-670.

福田匡, 阿佐部和孝, コンファインド型アトマイズノズルを用いて生成した合金粉末の粒度, 鉄と鋼, Vol.85, No.9 (1999), pp.703-709.

生井武文, 松尾一泰, 压縮性流体の力学(1977), 理工学社, pp.163-165.

稲村隆夫, 永井伸樹, 気流微粒化による噴霧の運動特性に関寸る研究（第 3 報、噴霧流動の数值シミュレーショ ン)，日本機械学会論文集 B 編，Vol.57, No.544 (1991), pp.4319-4326.

日本粉末治金工業会，平成 24 年度日本粉末治金工業会年報(2013), pp.3-6.

河合賢治，関義和，高田稔，佐久間均，村上政博，河合信也，アトマイズ鉄粉の開発と発展，神戸製鋼技報，Vol.50， No.3 (2000), pp.36-40.

Krauss, M., Bergmann, D., Fritsching, U. and Bauckhage, K., In-situ particle temperature, velocity and size measurements in the spray forming process, Materials Science and Engineering A326(2002), pp.154-164.

Lubanska, H., Correlation of spray ring data for gas atomization of liquid metals, Journal of Metals (1970), pp.45-49.

永井伸樹，噴霧生成と特性，第 20 回液体の微粒化に関する講演会講演論文集(1993), pp.19-28.

社河内敏彦, 噴流工学(2004), 森北出版, p.23, p.192.

Yule, A. J. and Dunkley, J. J., Atomization of Melts (1994), Clarendon press · Oxford, pp.16-25.

\section{References}

Fukuda, T., Nakanishi, M. and Kubo, T., Pressure distribution around the melt delivery tube for a confined-type gas atomization nozzle, TETSU-TO-HAGANE, Vol.82, No.8 (1996), pp.665-670 (in Japanese).

Fukuda, T. and Asabe, K., Particle size of atomized alloy powder prepared by using a confined-type atomizing nozzle, TETSU-TO-HAGANE, Vol.85, No.9 (1999), pp.703-709 (in Japanese).

Ikui, T. and Matsuo, K., Compressible fluid dynamics, Rikougakusha (1977), pp.163-165 (in Japanese).

Inamura, T. and Nagai, N., Spray flow characteristics in air blast atomization(3rd report: Numerical simulation of a spray flow), Transaction of the Japan Society of Mechanical Engineers, Series B, Vol.57, No.544(1991), pp.4319-4326 (in Japanese).

Japan Powder Metallurgy Association, Annual report of JPMA 2012(2013), pp.3-6 (in Japanese).

Kawai, K., Seki, Y., Takada, M., Sakuma, H., Murakami, M. and Kawai, S., Developments related to atomized steel powders, Kobe steel engineering reports, Vol.50, No.3 (2000), pp.36-40 (in Japanese).

Krauss, M., Bergmann, D., Fritsching, U. and Bauckhage, K., In-situ particle temperature, velocity and size measurements in 
the spray forming process, Materials Science and Engineering A326(2002), pp.154-164.

Lubanska, H., Correlation of spray ring data for gas atomization of liquid metals, Journal of Metals (1970), pp.45-49.

Nagai, N., Formation and characterization for atomizing, Proceedings of 20th conference on liquid atomization (1993), pp.19-28 (in Japanese).

Shakouchi, T., Jet flow engineering, Morikita publishing (2004), p.23, p.192 (in Japanese).

Yule, A. J. and Dunkley, J. J., Atomization of Melts (1994), Clarendon press• Oxford, pp.16-25. 